\title{
Utilization of Educational Programmes in Reformation of Prison Inmates in Nigeria
}

\author{
Ogbaka, Luke Chidiebele ${ }^{1}$ \\ Ewelum, Johnson Nnadi ${ }^{2}$ \\ Apiti Anthony ${ }^{3}$
}

${ }_{1,2, s}$ Department of Adult Education, Nnamdi Azikiwe University, Awka, Anambra State, Nigeria

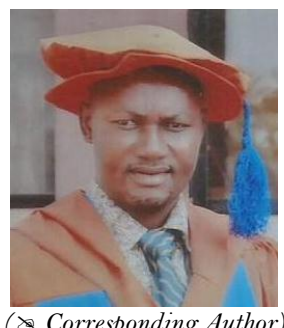

\section{Abstract}

Education is the most powerful instrument for change in behaviour. Reformation of prison inmates can only be achieved through education and training. Prison education is therefore an alternative strategy that would enable the prisoners leave the prison with more skills and be in position to be employed at released. This paper, therefore, discussed some concepts, purpose of prison education, educational programmes for prisoners and then came up with conclusion and recommendations.

Keywords: Reformation, Prison education, Prison inmates.

Citation | Ogbaka, Luke Chidiebele; Ewelum, Johnson Nnadi; Apiti Anthony (2017). Utilization of Educational Programmes in Reformation of Prison Inmates in Nigeria. Asian Journal of Education and Training, 3(2): 86-91.

History:

Received: 15 August 2017

Revised: 15 September 2017

Accepted: 22 September 2017

Published: 27 September 2017

Licensed: This work is licensed under a Creative Commons

Attribution 3.0 License (c))

Publisher:Asian Online Journal Publishing Group
Contribution/Acknowledgement: All authors contributed to the conception and design of the study.

Funding: This study received no specific financial support.

Competing Interests: The authors declare that they have no conflict of interests.

Transparency: The authors confirm that the manuscript is an honest, accurate, and transparent account of the study was reported; that no vital features of the study have been omitted; and that any discrepancies from the study as planned have been explained.

Ethical: This study follows all ethical practices during writing.

\section{Contents}

1. Introduction 87

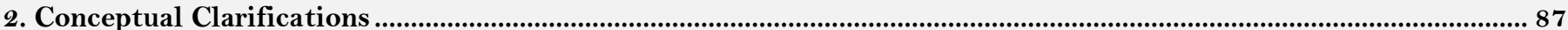

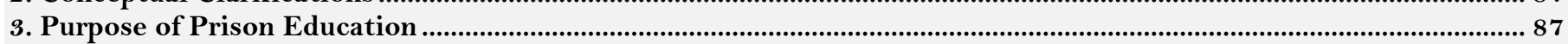

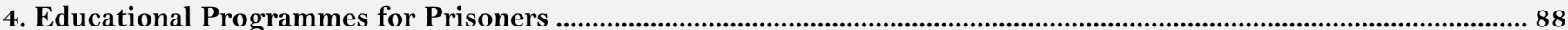

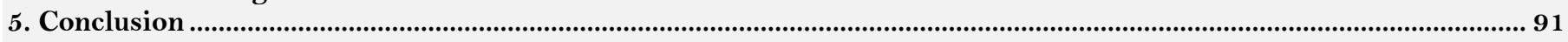

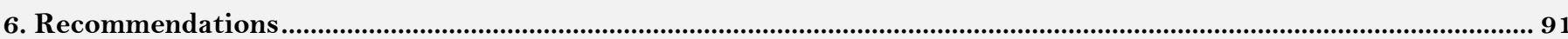

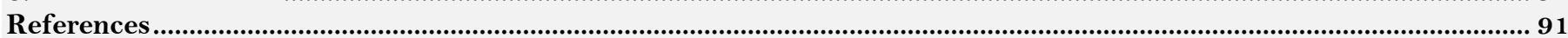




\section{Introduction}

One of the goals of Education for All (EFA) is equal education opportunities for all by the year 2015. Prisoners are not left out in this EFA goal so as to be integrated into the society after reformation. Reformation in this sense means correcting, educating, re-orientating and rehabilitating the inmates so that they could become better citizens when they are released from the prison.

According to Afujue (2004) some of the functions of the Nigerian prisons service are to treat, train and reform those legally charged and convicted so that on their discharge they could be useful to themselves and the society at large. Afujue further stated that those who have committed crimes should be assisted to live a good life rather than punishing them for the crime they committed. This view is predicated upon the understanding that those (offenders) who have broken the collective norms and laws of their societies as expressed in criminal laws of their societies are those who have had problems of adaptation and conformity with the general value system of their societies. Therefore, when they commit crimes, they are sent to prisons for reformation.

The Nigerian prisons service has to embrace prison education as a means of reforming prison inmates. This is because, statutory function of the prisons is to reform inmates and prepare them for crime free life (Human Rights Commission, 2005). According to Ogundipe (2008) the Nigerian prisons service has developed pragmatic educational strategies for reforming the prison inmates. These strategies according to him include Vocational Skill Development Programme (VSDP) which aims at empowering the prisoners with the needed skills for selfsustenance and actualization, and adult and remedial education programmes designed to help prisoners who were pursuing one academic programme or the other before their incarceration. VSDP enables prison inmates to learn skills in vocations such as tailoring, plumbing, carpentry, among others. This paper, therefore, is limited to conceptual clarification, purpose of prison education and educational programmes for prisoners.

\section{Conceptual Clarifications}

\subsection{Prison Education}

Prison education is a broad term that encompasses number of educational activities, occurring inside a prison. These educational activities include both vocational training, academic and general education. The goal of such activities is to prepare a prisoner for successful adjustment outside the prison. Education programmes that take place inside prisons are completely provided and managed by the prison authorities (Wikipedia, 2014). According to Rhode (2004) prison education is the form of education designed for prisoners to enable them leave the prison with more skills and be in a position to find meaningful employment or create employment. In agreement with the above definitions, prison education is education designed for prisoners to equip them with veritable skills and knowledge to enable them to be productive on release.

\subsection{Reformation}

The word "Reformation" has no specific definition. It varies from one author to another. According to Collins Thesaurus of the English Language (2002) reformation is an improvement in the existing form or condition of institutions or practices. It is also defined as the process of rescuing from error and returning to a rightful course. For the purposes of this study, reformation means changing from a sinful to a normal life. Thus, reformation of prison inmates means changing prison inmates from a sinful life to a normal life.

\subsection{Prison Inmate}

A prison inmate is a person who is deprived of liberty because he went against the law. This can be by confinement, captivity, or by forcible restraint. The term applies particularly to those on trial or serving a prison sentence in a prison. A prison inmate is also known as a prisoner or a detainee (Wikipedia, 2014). In section 1 of the American Prison Security Act 1992, the word "prison inmate or prisoner" means any person for the time being in a prison as a result of any requirement imposed by a court or otherwise that he be detained in legal custody. In Section 19 of the Nigerian Prison Security Act 1972, prisoner means any person lawfully committed to custody. Prisoner is a legal term for a person prosecuted for felony. It is not applicable to a person prosecuted for misdemeanour. In other words, prison inmate is any person legally held in custody.

\section{Purpose of Prison Education}

Prison or correctional education involves academic and vocational training designed mainly for prisoners' reformation. It is aimed at preparing prison inmates for living productive life at the time of acquittal. Prison education is provided by prison authorities and the voluntary organizations outside the prison. In the past, prison education was viewed as a means of keeping prison inmates occupied. Skeptics of this educational system argued that prison education in most cases has produced nothing but "better educated criminals". However, evidences abound in the literature to show that prison education has helped many prison inmates to be fully reformed so as to stay out of jail (Firefox, 2004).

Historically, prison education was introduced in the Nigerian prisons service in 1946 by Mr. R.H Dolan who was at that time the colonial Director of prisons. As part of the rehabilitation programme of the Nigerian prisons, he introduced vocational education (Kalu, 2002). According to Kalu (2002) the prison system at independence in 1960 was decidedly reformative as a result of the introduction of certain educational programmes for inmates and the establishment of the prison industries where prison inmates were trained on various skills and trades. The trades and vocations available at that time were carpentry, tailoring, wood and metal works, painting, weaving, masonry, fine arts, electrical works etc. In addition, adult and remedial education programmes were also introduced for prisoners' self-development

Prison education can open opportunities, enlighten prison inmates, broaden their horizons and build their selfconfidence. The Nigerian penal system is capable of producing the required changes in criminals (Idris, 2007). The over-riding aim of prison education is to ensure that the inmates get a new orientation that will help them reshape their lives so as to be better at the time of release. Prison education can make prison inmates to be aware of things 
that will help them not to engage in any criminal act if released. It can help them to engage in legitimate activities which will lead them to achieving success (Braggins and Talbort, 2000). One of the cardinal goals of correctional education is to reduce recidivism. Evidence abounds in the literature to show that prison education reduces the rate of recidivism (Lopinto, 2008).

Prison education practitioners now view prison education as an element of life-long education which its success cannot be determined only by a reduction in recidivism. The new thinking now is that prison education should provide prison inmates with opportunities for continuous education even after their jail terms. In agreement with this, Lopinto (2008) posited that one of the priorities of prison education is to support the principles of life- long education. Evidences in the literature suggest that prison or correctional education has achieved some successes in the Nigerian Prisons (Ogundipe, 2008). The reduction in recidivism has been the yardstick for measuring the success of prison or correctional education. The use of reduction in recidivism as standard for measuring the success of prison education possesses some problems as it is not possible to use it to study controlled groups and small sample (Lopinto, 2008).

There are some scholars who view prison as a means of strictly punishing the inmate and hold no interest in providing offender service programmes (Zimring and Hawkins, 1995). Other scholars suggest that there is sufficient evidence to prove the success of rehabilitation programmes and the need for increased government funding towards treatment programmes (Gehring et al., 1998). The programmes would help in correcting the behavior of the inmates before release to the society. In the same vein, Sutton (1993) noted that there are three main immediate objectives of prison education at the basic level namely: (i) To keep inmates meaningfully busy (ii) To change attitudes and behavior (iii) To enable employment, vocational skills and/ or advance to further education and training. Finally, Wolford (1989) suggests that the purpose of prison or correctional education can be classified into six key factors:

i. To provide inmates with basic academic and vocational skills

ii. To provide inmates with an opportunity to change their personal behaviours and values

iii. To reduce recidivism

iv. To provide passive control of inmates' behaviour

v. To support the operational needs of the correctional institution

vi. To provide institutional work assignments.

\section{Educational Programmes for Prisoners}

\subsection{Technical and Vocational Education and Prisoners' Reformation}

Vocational education was introduced in the Nigerian prisons service since 1946 (Kalu, 2002). This was as a result of the reform initiative of the then colonial government in Nigerian prisons. It is evident in the literature that most people commit crimes due to lack of a legitimate means of livelihood. Reformation programmes of the then colonial government were designed to equip prison inmates with the vocational skills and knowledge that will help them to settle down in some vocations on their release back to the society. Vocational education programmes in prison involve instruction for a specific trade, occupation or vocations such as welding, auto repair, building maintenance, and graphic arts. The primary goal of vocational education is to help offenders develop marketable job skills upon release to the community.

Vocational training or career technical education programmes in prison are designed to teach inmates about employment skills or skills needed for specific jobs and industries. The overall goal of vocational training is to reduce inmates' risk of recidivating by teaching them marketable skills they can use to find and retain employment following release from prison. Vocational and technical training programmes in handicraft and other trades such as barbing and electrical works can reduce anti-social behaviour by replacing inmates' idle time with constructive work (Wilson et al., 2000). In addition, some vocational training programmes can assist in the operation of prisons by having inmates assist in institutional maintenance tasks.

There are several obstacles that incarcerated adults must face upon their release from prison, including the prospect of unemployment. A lower level of educational attainment, an absence of a steady history of employment and a lack of vocational skills can hinder effort to find a job and make a decent wage. Providing educational programmes and vocational training to adults while they are in prison can help them overcome these challenges by fostering the skills needed to find employment (Davis, 2014). Most of our educated youths lack competences in vocational trades that would have enabled them to secure employment. According to the Punch Newspaper as cited by Ogundipe (2008) 64 million youths in the country are jobless. He lamented that the implication of this was a frustrated youth population with the tendency towards vices such as prostitution, cultism, armed robbery, drug and child trafficking, kidnapping and hostage taking.

Education without competences in certain vocational trades is likely to make recipients not to secure employment on time. Non- formal education system is the most effective approach to deliver quality education to most prison inmates. According to the Independent Newspaper as cited by Ogundipe (2008) beneficiaries of nonformal education performed better in business transactions through effective communication, better bargaining and self-employment. Vocational training equips the recipients with the necessary skills needed for proficiency in one's chosen vocation.

\subsection{Civic Education and Prisoners' Rights in Nigerian Prisons}

Civic education is a critical and effective empowerment tool for promoting citizen participation in democratic processes. It empowers citizens, both as individuals and as part of collective groupings. All citizens-male and female; young and old; civil servants, politicians; rural or urban can benefit from civic education. Civic education is an important aspect of prison education. It inculcates national values, norms and aspirations in the minds of the citizens. Citizens are made to know their basic rights and social obligations through civic education. According to Ani (2003) civic education enables an individual to learn how to do something for the betterment of his country or community, function as a socio-economic agent such as an active member of a trade union or a cooperative society and also participate in politics actively by learning how to vote or understand a new constitution. 
Civic education is targeted at people who are potential victims of human rights abuse in the society. This group includes the rural poor, minority groups, street children and other marginalized people such as the incarcerated. These groups of people are exposed to human rights abuse and repressive violence. Repressive violence is the most common form of human rights violation. According to Schweitzer et al. (2006) repressive violence occurs when there is violations of the civic rights such as denials of freedom of thought, religion and movement or equality before the law including the right to a fair hearing. Civic education is very important, especially in the prisons where the prisoners' rights are violated. Most of these prisoners are not aware of their rights and social obligations as citizens of the country. Prisoners are not totally stripped off their rights as citizens of their countries or as human beings just because they are being incarcerated. They are protected by series of rights and other legal

The 1979 constitution of the Federal Republic of Nigeria makes elaborate provisions for safeguarding the fundamental human rights of her citizens. These rights are provided for in chapter IV, section 30-39 of the constitution. These provisions laid down the circumstances in which a person in Nigeria may be deprived off his or her rights or liberty and in this way provide the constitutional basis for our prison systems (Agomoh et al., 1999). The prisons regulation of 1974 is a set of rules designed to ensure that the country's prisons service complied with the UN Standard Minimum Rules for the treatment of prisoners. The prison regulation is divided into three parts namely: part I, part II and part III. Part I deals with matters concerning the procedure for admission and discharge of prisoners. Part II handles the core duties of all the prison staff while part III provides for the rights, privileges and powers of visiting committees (Agomoh et al., 1999).

The United Nations Standard Minimum Rules for the treatment of prisoners, (UNSMR) is a compilation of 95 rules made by the UN in 1955 and approved in July 1957. According to Agomoh et al. (1999) the prisoners' rights enshrined in these rules are:

i. The right to life and integrity of the person

ii. $\quad$ The right to be free from torture or other ill-treatment.

iii. The right to health

iv. The right to respect human dignity

v. The right to due process of law

vi. The right to freedom from discrimination of any kind.

vii. The right to freedom from slavery

viii. The right to freedom of thought.

ix. The right to freedom of religion

$\mathrm{x}$. The right to respect family life

xi. The right to self-development.

Despite the fact that Nigeria is a signatory to these international legal instruments, prisoners' rights are still violated in the Nigerian prisons with impunity. According to the Guardian Newspaper as cited by Ogbodo (2011) nobody goes through the Nigerian prisons system without being traumatized. The Amnesty International report as cited by The Vanguard (2008) and The Punch (2008) maintained that people were convicted without fair trial and in some cases were not offered the services of a lawyer throughout the proceedings.

\subsection{Recreation, Leisure and Prisoners' Self-Development}

Recreational activity is a medium in which participants can change their self-image and gain personal satisfactions. Development of a positive self-esteem and self-image is important among prisoners. It is also an important aspect of correctional education. This is because prison inmates generally feel dejected and have a very low self-esteem. Improving prison inmates' self- esteem will help them regain confidence in their ability to live a positive life. According to Frank and Gustafson (2001) consistent physical activities increase self-esteem. Recreational and physical activities improve mental engagement and increase self-awareness, clarification of values, creative engagement and spiritual renewal among those that participate in it. This assertion was supported by Tarrant et al. (1994) who stated that physical and recreational activities enhance personal and social system.

Recreational activities are designed to teach inmates how to make good use of their leisure time, how to relax and engage themselves in recreational activities such as playing or listening to music, reading, watching movies or $\mathrm{TV}$ and gardening, among others in order to reduce tension and depression. Recreational programming is meant to provide inmates with physical, mental and emotional outlets to enhance their well-being. Prison recreation programmes offer numerous benefits to inmates and correctional staff alike. Sport can reduce tension and stress while promoting good health and well-being. It is thought to prevent major diseases like cancer, cardiovascular diseases and diabetes (Geoffrey and Wanda, 2004). A number of activities like football and basketball are specifically designed to help reduce the stresses of incarceration by providing physical stimulation. Other courses like art, writing and music provide more creative outlets. Some prisons have music bands that perform for the prisoners or provide opportunities for incarcerated artists to sell their artwork. Recreation increases discipline and creativity, self-esteem, and improves positive socialization skills, which help reduce re-offending (Geoffrey and Wanda, 2004).

Today, recreation is a vital aspect in almost all prisons. Advocates for prison recreation argue that recreation is used as a therapeutic tool, and it may reduce recidivism. The benefits and skills that inmates obtain from exercise, such as time management, wellness, stress relief and anger management, will assist them in the community as well. Sport and leisure programmes sometimes create incentives for participation as well as developing skills: Prisoners develop pride in winning in sporting events, or in improving themselves in writing, acting and public speaking. Recreation programmes also awaken skills or encourage prisoners to renew their interest in developing previous skills. This allows for a smoother transition back into the society (Geoffrey and Wanda, 2004). Recreation and leisure can also be used in fighting depression. Depression is psychological disorder which comes in various forms. It is a mental illness that has the following symptoms; Feelings of loneliness, despair, hopelessness and worthlessness, unshakeable sadness and diminished interest in group activities (Minino et al., 2002). They reported that as a result of depression alone, 29,350 people committed suicide in the United States in the year 2000 which 
made it the third major cause of death in the United States among adults between the age of 15 and 24 years that year.

Participation in recreational activities provides relief from alienation, loneliness and isolation. According to participation in outdoor activities increases self-esteem, lowers depression and reduces suicide rate. Thus, recreation and leisure can be of immense benefits to prison inmates for fighting depression and improving selfimage and self-esteem.

\subsection{Health Education Programmes and Prisoners}

Health education programmes in prison are programmes designed to promote healthy living among inmates. Provisions and promotion of good health and sanitary practices are enshrined in the United Nations Standard Minimum Rules for the treatment of prisoners (UNSMR). Many countries including Nigeria are signatories to these rules and other basic human rights provisions as enshrined in the international legal instruments. Specifically, Rule 22 of the UNSMR Stipulates that:

i. Every prison should make the services of a qualified medical officer available to the prisoners.

ii. A qualified dental officer should be available to every prisoner (Agomoh et al., 1999).

Despite the fact that Nigeria is a signatory to these rules, medical and sanitary conditions in Nigerian prisons remained in poor state. In agreement with this, the Civil Liberties Organization (1993) reported that medical and sanitary conditions in the Nigerian prisons are nothing one can write home about. A functional health and good sanitary practices in the prisons can be an effective tool for the reformation of prison inmates, especially the mentally impaired who are criminal lunatics.

Finally, physical education provides opportunities for those incarcerated to release tension, boredom and achieve psychological and social rejuvenation. Physical education in the prison is also important in that it will empower prison inmates to cope with the dilapidating health system in the prisons. Healthy mind promotes healthy body. Emotional health of prison inmates is as important as their physical health. Most often, prison inmates are overwhelmed by the weight of their past infamous life styles. This condition makes them relapse into depression.

\subsection{Family Life Education and Prisoners' Reformation}

Family life education programme as an aspect of prison education is aimed at helping prison inmates maintain healthy relationship between them and their family members. It is designed to rejuvenate deteriorated family relationship between the inmates and their family members (Bayse et al., 1991). There is a great responsibility on the part of the family members of the prison inmates to help them repair their already damaged personality. Evidences abound in the literature to show that inmates who learnt how to repair and maintain their family relationships have lower recidivism rates and less disciplinary problems within the prison system (Brodsky, 1995). Incarcerated people often look upon their family relations as the last resort for affection and love (Amuchie, 2003).

According to the National Council on Family Relations (2002) Family life education is the educational effort to strengthen individual and family life through a family perspective. The objective of family life education is to enrich and improve the quality of individual and family life. Inmates always enter prison with their family relationships in distress and rapidly deteriorating According to Jeffries et al. (2001) communication between prisoners and their families provides the most concrete and visible strategy that families and prisoners use to manage separation and maintain connections. Families visit their imprisoned relatives at the institutions where they are held, talk with them by phone, and exchange cards and letters as a means of staying connected.

These contacts allow adults, parents and children to share family experiences and participate in family rituals, for example, birthday celebrations, and religious observations, among others and help them to remain emotionally attached. They help assure incarcerated parents that their children have not forgotten them and children that their parents love and care about them. Most prisons for women, and a few for men, provide parent education courses and a few offer other parenting supports including counseling, parent support groups and special visiting areas and programmes for parents and their children (Jeffries et al., 2001). Family life education can be used in reducing narcissistic behaviour among prison inmates. Narcissistic individuals have poor relationships as they are not able to show empathy and try to exploit those they associate with American Psychiatric Association (1987).

\subsection{Basic Literacy and Prisoners' Reformation}

According to the American English Doctor (n.d) basic literacy has to do with enabling a person to read, without difficulty; read, with understanding, a non- fiction book or speak a standard form of the native language whenever required and write a simple coherent note or letter that conveys the person's thoughts. It emphasizes teaching of reading, writing and computations. The philosophy behind the adoption of this type of literacy approach is to help recipients acquire the necessary skills and knowledge that can be applied immediately for solving socio-economic problems.

According to UNESCO (1972) the very process of learning to read and write should be made an opportunity for acquiring information that can immediately be used for improving standards. Basic literacy is popular among prison education practitioners. This is because of the belief that prison inmates should be helped to acquire reading, writing and computational skills and knowledge that will help them to be productive if released back into the society. Prison inmates generally are people with poor reading, writing and computational skills, and are school drop- outs. Basic literacy programme can be employed to help these inmates acquire skills (reading, writing and computational skills) and competencies that will make them to become better on their release. According to British House of Commons (2004) half of all the prisoners in the UK were at or below the level expected of an 11 years old in reading, two-third in numeracy and fourth-fifth in writing. Basic literacy makes it possible for the recipients to apply what they have learnt in literacy classes to their everyday activities. 


\section{Conclusion}

From the foregoing, it can be deduced that reformation of prison inmates is a core function of Nigerian Prison Service which can be achieved through educational programmes and training to equip the prisoners with useful skills before release. Prison education programmes open up opportunities, enlighten prison inmates and build their self-confidence which has been depleted by incarceration. Such programmes include technical/vocational, civic, recreation, leisure, family life health and basic education programmes. It is expected that when the programmes are fully implemented, the problem of recidivism would be solved.

\section{Recommendations}

The following recommendations are made:

1. The government at all levels should recruit qualified instructors and counsellors who will impart the desired knowledge and skills into the learners that would be useful to them when they are released.

2. The government should also make provision for adequate facilities (including health facilities) to be used in all the prisons. This would help to curb some casualties that may occur in prisons.

\section{References}

Afujue, C.R., 2004. Case for prison reform. Reformer, 1(5): 34-46.

Agomoh, U., L. Mozzanica and B. Agozimo, 1999. Towards good standard: A manual for prison officers. Lagos: Prisoners Rehabilitation and Welfare Action.

American English Doctor, n.d. Basic literacy. Retrieved from americanenglishdoctor.com/.

American Psychiatric Association, 1987. Diagnostic and statistical manual of mental disorders. 3rd Edn., Washington, D.C.: American Psychiatric Association.

Amuchie, F.A., 2003. Science, technology and health education in Nigeria. Journal of Health Education, $2: 4$.

Ani, R.O., 2003. An introductory approach to the study of adult education. Enugu: Donsinbad Communications.

Bayse, D.J., S.M. Allgood and P.H.V. Wyk, 1991. Family life education: An effective tool for prisoner rehabilitation. Journal of Family Relations, 40(3): 254-257. View at Google Scholar | View at Publisher

Braggins, J. and J. Talbort, 2000. The role of prison officer in supporting prison education. London: Centre for Crime and Justice Studies.

British House of Commons, 2004. Education and skills (seventh report). Retrieved from http://www.publication.Parliament.UK.

Brodsky, S.I., 1995. Families and friends of men in prisons: The uncertain relationship. Lexington: Lexington Books.

Civil Liberties Organization, 1993. Prisoners in the shadows. Lagos: Civil Liberties Organization.

Collins Thesaurus of the English Language, 2002. Complete and unabridged. 2nd Edn.: Harper Collins Publishers.

Davis, L.M., 2014. How effective is correctional education, and where do we go from here? , Washington, D.C.: US Department of Justice, Office of Justice Programs Bureau of Justice Assistance.

Firefox, M., 2004. Correctional education, adult basic education and literacy. Retrieved from http:// www.//en.wikipedia.org.

Frank, M.A. and S. Gustafson, 2001. The reciprocal influence of self-esteem and exercise. Retrieved from http://www.behaviouralconsultants.com.

Gehring, T., M. Meshane and C. Eggleston, 1998. Then and now: Approaches to correctional education in the United States. In W. Forster (Ed.), Education behind bars: International comparisons. Leicester, England: National Institute of Adult Continuing Education. pp: $147-166$.

Geoffrey, T. and T.H. Wanda, 2004. Recreation programs. Encyclopedia of prisons and correctional facilities. Thousand Oaks, CA: SAGE.

Human Rights Commission, 2005. Towards a reformative prison service. Human Rights, 15(1): 9-12.

Idris, M., 2007. Ex-robber writes books on evil effects of crime. Vanguard: 11.

Jeffries, J., S. Menghraj and C.F. Hairston, 2001. Serving incarcerated and ex-offender fathers and their families. New York: Vera Institute of Justice.

Kalu, O.U., 2002. Role of prisons service in the enforcement and maintenance of law and order in Nigeria. Reformer, 1(2): $19-26$.

Lopinto, B., 2008. Prison education: Measuring success. Retrieved from http://www.adulted.about.com.

Minino, A., E. Arias, K. Kochanele, S. Murphy and B. Smith, 2002. Death” final data for 2000. National Vital Statistics Report.

National Council on Family Relations, 2002. Annual report. Retrieved from en.wikipedia.org/wiki.

Ogbodo, F.U., 2011. Perceived effectiveness of selected adult education programmes in reforming prison inmates in the South East zone of Nigeria. Unpublished Master's Degree Thesis. The University of Nnamdi Azikiwe, Awka.

Ogundipe, O.A., 2008. Education behind bars: The Nigerian experience. Reformer, 3(3): 32-38.

Rhode, L., 2004. What's wrong with prisoners hearts and minds networks. Retrieved from http://www.employeradvisorsnetwork.com/documents/21stcenturyfirm.pde.

Schweitzer, E.R., V. Greeney and K. Duer, 2006. Promoting social cohesion through education: Case studies and tools for using textbooks and curriculum. Washington: World Bank.

Sutton, P., 1993. Basic education in prisons' inmate on the project of the UNESCO institute of education. Europe: Prison Education Association.

Tarrant, M.A., M.J. Manfredo and B.C. Diver, 1994. Recollections of outdoor recreational experience: A psychological perspective. Journal of Leisure Research, 26(4): 357-371. View at Google Scholar

The Punch, 2008. Spare 736 condemned prisoners. Amnesty International Report: pp: 9.

The Vanguard, 2008. Yar adua should end capital punishment. Amnesty International Report: pp: 6.

UNESCO, 1972. Find report of the third international conference on adult education. Tokyo Japan, Paris: UNESCO.

Wikipedia, 2014. Prison education. Retrieved from http://www.wikipedia.org/wiki/prisoneducation.

Wikipedia, 2014. Prisoner. Retrieved from http://www.wikipedia.org/wiki/prisoner.

Wilson, D.B., C.A. Gallagher and Mackenzie, 2000. A meta-analysis of corrections-based education, vocation, and work programs for adult offenders. Journal of Research in Crime and Delinquency, 37(4): 347-368. View at Google Scholar | View at Publisher

Wolford, B.I., 1989. Correctional facilities. In S.B. Merrian \& P.M. Cunningham (Eds), Handbook of adult and continuing education. San Franasco: Jessey Bass.

Zimring, F.E. and G. Hawkins, 1995. Incapacitation: Penal confinement and the restraint of crime. New York: Oxford University Press. 